\title{
New Model Exploration of Practice Education in Higher Education
}

\author{
Honglin Tang ${ }^{1}$ \\ ${ }^{1}$ Guangdong Mechanical \& Electronical Polytechnic, China
}

Keywords: higher education; practice education; education model; explore

\begin{abstract}
Practical education is an important aspect of talent training in colleges and universities. It is an important measure to deepen the teaching reform of higher vocational education and promote quality education. The practice of educating people has a special position and role in the process of education and teaching in colleges and universities. It requires meticulous organization, innovative training mode, scientific design route, and promotion of connotation construction in order to promote the continuous improvement of the quality of personnel training.
\end{abstract}

\section{Introduction}

Promoting the practice of educating people is a comprehensive implementation of the country's education policy, putting the socialist core value system throughout the entire process of national education, in-depth implementation of quality education, and vigorously improving the quality of higher education. The practice of education is an important part of higher vocational education, and it is an important part of improving the quality of personnel training [1]. To carry out innovative research on the practice training model has become an entry point and breakthrough point for improving the quality of personnel training in higher vocational colleges. It is an important way for students to consolidate their professional skills, improve their professional qualities, and foster theoretical links with practical styles. It also helps students develop practical skills. With the spirit of innovation there is a special role that theoretical teaching cannot replace.

With the development of the times, the practical education system as an important part of the ideological and political education of college students is training high-quality talents and guiding the majority of young students to correctly understand the dialectical relationship between theory and practice, thereby better self-improvement and self-improvement in practice. The above opinions have, to a large extent, elevated the practice of educating people in colleges and universities to a new height, requiring that all universities and colleges recognize the new situation of practicing educating people in the new situation, grasp new laws, explore new methods, and achieve new development.

\section{The Basic Idea of Innovative Practice and Education}

In recent years, the State Council and the Ministry of Education have issued a series of documents concerning the enhancement of the practice of educating people. They have made demands on the importance of practice and education, overall planning, and organization and leadership. They are required to be oriented towards vocational needs and cultivate practical ability for higher vocational education. Focus, strengthen the practice of teaching, improve the level of teacher education, etc. The practice of educating people in universities emphasizes the unity of university students' adherence to theoretical study, innovative thinking and social practice, persists in learning from practice, learns from the people, and continuously strengthens the students' service to serve the people's social responsibility, the innovative spirit of exploration, and the ability to solve problems [1]. To this end, the practice of educating people in colleges and universities should adhere to Deng Xiaoping Theory and the important thinking of the "Three Represents" and the scientific outlook on development as the guideline, fully implementing the party's education policy, and effectively changing the concept of emphasizing theory and practice and emphasizing the cultivation of light knowledge. Follow the laws of cognizance, education and teaching, and the law of growth of talents, insist on moral education as the first step, stand up for the tree, integrate the socialist core value system into the whole process of 
the practice of educating people, and take the social economic development as a guide to the demand for talents' practical ability. We must make the practice of educating people a useful extension, extension, and supplement of school education. We must strive to combine practical courses with subject knowledge, combine with the reality of life, integrate with modern science and technology, and integrate with local culture [1].

\section{The Significance of Building the Efficient Mechanism of Cultivating People in Colleges and Universities}

The practice of education is a systematic, comprehensive, and holistic project. "It is not only a matter of 'education', but also 'education' [2]," is the key to the modernization of higher education, and it is also the basic way for young students to grow into talents. . The practice of educating people is a scientific education concept that is based on respecting the law of education development and the law of personnel training, and is a deepening of Marxist view of practice. The practice of educating people in colleges and universities is an organic combination of principles, contents, and methods for the practice of educating people in colleges and universities. It provides the necessary means or tools for the realization of educational purposes. Further explore the effective mechanism for the practice of educating people in colleges and universities. "Strengthening the practice of educating people in colleges and universities is a comprehensive implementation of the party's education policy, putting the core values of socialism throughout the entire process of national education, in-depth implementation of quality education, and vigorously improving the quality of higher education [1]."

\subsection{An inevitable requirement for the realization of education task and the overall improvement of the quality of higher education.}

It is the fundamental task of education. Doing a good job of educating people is the premise of doing a good job of liking people. The practice of educating people provides a guarantee for achieving education goals and is one of the basic ways to educate people. "The combination of productive labor with intellectual education and sports is not only a way to increase social production, but also the only way to create a person who develops in an all-round way [3]. The practice of educating people works organically and integrates intellectual education and sports. The subjective initiative and initiative of college students have been brought into full play, which has greatly promoted the in-depth development of college moral education. Under the background of coordinating the development of world-class universities and first-rate disciplines, the State Council puts forward "all kinds of innovative, applied, and composite talents who are focused on cultivating a sense of historic mission, social responsibility, innovative spirit and practical ability [3]." This requires universities and colleges to constantly change the mode of personnel training, training both academic and applied talents as well as cultivating both academic and applied talents. The practice of educating people in colleges and universities, which combines theoretical learning with social practice, is the basic approach for the cultivation of new, applied, and compound talents.

\subsection{An important guarantee for promoting people's all-round development and building an innovative country and a strong human resource.}

The university's practice education system builds a teacher-led, student-centered, teacher-student combination of teaching practice, social practice, and research practice, communicates in-class and out-of-class, connects learning and application, and connects professional knowledge and ability with people. The organic integration of social development helps college students acquire rich practical experiences and spiritual experiences, making them fully aware of the value of human beings. While comprehensively improving the ability of college students in all aspects, the comprehensive quality of college students is improved so as to achieve personal and social development. The practice of educating people in colleges and universities is an important support for promoting people's all-round development and building an innovative country and a strong human resource country. Xi Jinping pointed out that "national development depends on talents, national rejuvenation depends on talents, and talents must thrive" [3]. 


\subsection{The key to following the law of talent growth and enhancing the effectiveness of educating people.}

"Practice" is the basic point of view of Marxist theory. Social practice is the fundamental way to realize man's all-round development, and it is a ladder for personal growth, progress, and development. Practical education is the only way and fundamental way to turn knowledge into a 'spiritual' character of ability., is a decisive factor in the growth of talent" [4]. The overall development of college students is not only reflected in the continuous improvement of the level of knowledge and the continuous enrichment of the knowledge structure, but also requires the comprehensive improvement and coordinated development of students' various abilities and qualities. On the basis of personal development, we will meet the needs of social development and realize the harmonious development of individuals and society. Actively establish a mechanism for educating and educating people in institutions of higher learning, guide college students to participate in exercises and education in practice, consolidate theoretical knowledge in practice, and improve their practical ability to cope with difficulties, withstand setbacks, analyze problems, and solve problems.

\section{The Status Quo of the Practice of Educating People}

\subsection{The existing mode of practice innovation and lack of long-term effectiveness.}

The practice of educating people in colleges and universities is aimed at the majority of young students in the school. On the basis of better mastering professional basic knowledge, they will deepen society and life, integrate their own learning into social practice, and then learn and improve their learning through social practice [4]. Tracing the origins is an auxiliary work for resuming students' practical ability after the college entrance examination at the beginning of reform and opening up. Although after more than 30 years of exploration and development, the practice of educating people has achieved great results in the country, but the traditional practice education system with the content of "practical teaching, military training, and social activities" is taken as the content. In the past century, higher education took full advantage of the extracurricular time of students, and enriched the second-class steps of the students' classrooms and still played a major role.

\subsection{Optimize the content of teaching in practice.}

When majors revise personnel training programs, they must improve the content of practical teaching. Handle the relationship between theoretical teaching and practical teaching, and design and theoretical teaching systems are independent, complementary, and mutually permeable to practical teaching content elements. The professional practice education can build a practical teaching system in three major forms: professional recognition practice, basic practice, specialty practice, and applied practice, and three major forms of practical teaching, military training, and social practice activities [5]. At the same time, the professional practice education program should be linked to the talent training program and be coordinated with the principled opinion of the school to develop a talent training program. The professional practice education program should pay attention to the combination of in-class and extracurricular activities, the combination of professional and professional external, and the combination of on-campus and off-campus.

\subsection{Research on innovation mechanism of practice education system.}

The innovative talent cultivation model has always been an important part of the education system in our country, and it has a crucial role in promoting the growth of young college students and improving the internal structure of education. It is the only way for a modern university to develop its talents through practical knowledge, practical training of talents, and continuous practice of "adhere to ability, optimize knowledge structure, enrich social practice, and strengthen ability training." The long-term mechanism for cultivating people and innovating innovations is based on summarizing the previous work experience in the practice of educating people, uniting knowledge, integrating resources, and collaborating on innovation. It is through the idea innovation, method innovation, carrier innovation, and system innovation through practice education to achieve training [4]. Meet the 
goals of today's talented people.

\subsection{The development of the times puts forward higher requirements for talents.}

According to the overall layout and promotion effect of the Party's strategy of "rejuvenating the country through talents", the State has put forward the major proposition and major tasks of "practical education" in accordance with the achievements of previous social practice activities. In 2012, "Some Opinions on further strengthening the practice of educating people in colleges and universities" clearly stated that it is necessary to accelerate the construction of a practical education system, optimize the allocation of educational resources, and rationally deploy and upgrade the level of personnel training in order to adapt to the development of a modern society [5]. The innovative long-term mechanism is an effective measure that combines the requirements of the times, innovates courageously, and at the same time achieves long-term success, thereby advancing and safeguarding the long-term development of practical education.

\section{The Construction of Practice Education Mode}

In recent years, in-depth implementation of quality education practices and the full implementation of the core values of socialism are an important part of the implementation of our party's education policies and policies, while innovative university education models have guided contemporary college students to better integrate knowledge learned with social practice. Insisting on deepening practice and paying attention to social hotspots and fully tapping the inner potential of young students and enhancing their innovative spirit and practical ability are the proper meanings of educational development [5]. Efforts should be made to mobilize organizers and participants in the practice of educating people, and to care for and pay attention to practice. The personnel who work, and even the role of the whole society, expand the breadth and depth of the practice of educating people, tap various high-quality resources, innovate new modes of practice and educate people, ensure orderly conduct of educating people in practice, and truly realize practical training. A person's full-scale, full-scale and three-dimensional, so that the practice of educating people to maximize the play.

\subsection{The overall goal of the practice of educating people is at the core.}

The practice of educating people is an important means of cultivating talents. The development of their work has always been combined with the goal of cultivating talents. Without this goal, blindness and arbitrariness will occur in the practice of educating people [4]. Therefore, first of all, in terms of time and space, whether it is a long-term or a periodical, school-based or off-campus sociality, the themes of practice and education should be designed on the basis of overall goals. Secondly, in the specific content of the work and the forms and carriers of the activities, we should closely focus on the theme of the design. We should focus on the focus, difficulties, and innovation as the starting point for practice and educating people. We must design unique practices. Third, on the operational mechanism, we must dare to include "practice" in student inspections, student semester course settings, teaching staff training programs, and student education, so that "practice" becomes a required course for contemporary young students. In the specific implementation, project-oriented, order-based work methods can be used to carry out beneficial experiments. In the evaluation and protection mechanism, schools, governments, and the society participate in joint efforts to try public welfare crowd funding under the supervision and management of the government.

\subsection{It is an important construction principle for students to grow into talents.}

Whether or not the practice educating people evaluates effectiveness is based on whether the practitioner can solve practical problems in the process of the stage and the long-term. After more than 30 years of development, great achievements have been made in the practice of educating people. The practice content is also getting closer to the needs of social change and talent training. However, due to the inconsistencies in a series of reform measures such as the management system, personnel system, and resource allocation methods, the problem of overstaffing and quick success has emerged. 
In addition, in the practice of educating people, due to the influence of the traditional education concept, the students and their parents are slow to change their ideological concepts [6]. In addition, many departments are supported by a wait-and-see attitude, and lack the support of human, material, and financial resources. In the case of safeguards, practice activities often cannot be sustained and do not achieve the desired results. There are some problems in the evaluation and evaluation mechanism of the current practice activities, leading to the image project of media reports and form packaging becoming the main goal of the pursuit of practical activities, lacking the actual participation of the college students and the actual educational effectiveness of practical activities.

\subsection{Improve the level of educating and teachers.}

Teachers and students are two different roles in the practice education system. From the perspective of the division of roles in the practice of educating people in colleges and universities, we must give full play to the leading role of teachers; adhere to the main body of students, and work together to help students grow into talents. Encourage and support teachers, especially young and middle-aged teachers, to regularly go to work or training in industry and business units to enrich their practical experience and enhance teachers' practical teaching ability and education level [6]. Actively introduce professional talents with rich practical experience and enthusiasm in education and education to enter schools to enrich and educate teachers. Vigorously carry out innovation and entrepreneurship teacher training, employ entrepreneurs, professional and technical personnel and skilled craftsmen as part-time teachers. Employing and educating the students in the same way as the classroom teaching, the same amount of work is included in the workload, and the same shall be included in the annual assessment. The same evaluation award shall be given first to improve the enthusiasm of the teachers in their practice and education.

\section{Conclusion}

The practice of educating people in colleges and universities is a long-term and systematic project. It is necessary to adhere to the goal of cultivating talents to guide the various processes of practicing educating people, and to ensure and promote the smooth and effective implementation of the practice of educating people through innovative long-term mechanisms. We must firmly establish the educational concept of "people-oriented education and practice education", aim at improving the ability of university students to solve practical problems and cultivate the spirit of exploring and innovating, and realize the long-term sustainable development of practical education, in order to

cultivate Chinese characteristics. Socialist qualified builders and reliable successors provide strong guarantees.

\section{References}

[1] L.L.Yuan and Zh.H. Yao, Research on the methods and ways of practical education in higher vocational colleges, Journal of Hubei Institute of Industry and Technology, 2014, vol.12, pp.12-16.

[2] X.J. Hu, Analysis of the teaching team's practice of educating people in higher vocational colleges, Northern Literature, 2015(10):115.

[3] Y.L. Li and F.L. Liao, Construction and practice of higher education system, Vocational and Technical Education, 2015, vol.9, pp.44-45.

[4] Z.J. Yao, Analysis of innovation and practice of higher vocational college, Modern Enterprise Education, 2014, vol.5, pp.100-101.

[5] P.Y. Jie, Reflections on the "Multi-party Co-construction" Practice Model of Collaborative Innovation, Journal of Jiamusi Institute of Education, 2014, vol.6, pp.61-63.

[6] G.T. Lin, College of educational practice, Journal of china west normal university, 2015, vol.1, pp.165-166 